\title{
THE CORRELATION BETWEEN CRITICAL THINKING AND WRITING ACHIEVEMENT AT THE THIRD SEMESTER STUDENTS OF ENGLISH EDUCATION DEPARTMENT IN STKIP PGRI SUMBAR REGISTERED 2018/2019 ACADEMIC YEAR
}

\author{
Siziah Juandri, Elmiati, Riny D Sani \\ Program Studi Pendidikan Bahasa Inggris STKIP PGRI Sumatera Barat \\ siziahjuandri226@gmail.com
}

\begin{abstract}
ABSTRAK
Penelitian ini dilatarbelakangi oleh ketertarikan peneliti untuk mengetahui adanya hubungan antara berpikir kritis dan pencapaian menulis mahasiswa STKIP PGRI Sumbar. Tujuan dari penelitian ini adalah untuk mengetahui seberapa eratkah hubungan antara berpikir kritis dan pencapaian menulis mahasiswa STKIP PGRI Sumbar. Penelitian ini dilakukan dengan menggunakan penelitian kuantitatif dengan metode correlation. Peneliti menggunakan determining sample size sebagai cara untuk pengambilan sampel dalam penelitian ini. Dalam penelitian ini peneliti mengambil 4 lokal mahasiswa program studi pendidikan bahasa inggris tahun akademik 2018 sebagai sampel dari penelitian ini. Karena keterbatasan data dan sulit menemukan data dikarenakan hal-hal tertentu, peneliti mengambil 2 kelas sebagai sampel dalam penelitian ini, yaitu kelas 2018 A dan kelas 2018 B. Peneliti menggunakan tes dan dukumen sebagai instrumen untuk penelitian ini. Hasil dari penelitian ini menunjukkan bahwa adanya hubungan antara berpikir kritis dan pencapaian menulisnya sebesar rxy $=0,635$ dengan tingkat hubungan yang menengah. Kemudian peneliti juga menemukan hasil penelitian $t_{\text {hitung }} 4,360$ dimana lebih besar dari $t_{\text {table }}=0,3610$. Ini menunjukkan bahwa $\mathrm{H}_{1}$ untuk penelitian ini diterima dan $\mathrm{H}_{0}$ ditolak. Dengan demikian bisa disimpulkan bahwa berpikir kritis memiliki hubungan dengan pencapaian menulis mahasiswa di STKIP PGRI Sumbar meskipun dalam tingkat yang menengah.
\end{abstract}

Kata Kunci: Berpikir Kritis, Pencapaian Menulis.

\section{INTRODUCTION}

In education, writing is an important skill to express the ideas in written text. The writers can do anything through their writing. Through writing they can create essay, article, novel, fairy tale, and so on. They can develop the ideas on a paper. Writing called as a tool to communicate, because by writing activities, people can share what they think and feel. Therefore, students have to write well. If they write well, the readers will enthusiasm for reading and enjoy their writing.

The students have to create good and interesting essay. So, the students need to learn and practice to produce 
a good piece of writing. Also, the students must understand about the pattern of the essay. Then, the students must understand the rules of writing. To create good and interesting essay, the students can practice grammar structures, develop their vocabulary, and try to use punctuation in effective way. The last one, the students have to practice more to write an essay.

However, now a days most of students seem do not write and create a good essay. It is because they have did not apply their critical thinking in writing. Therefore, they have did not had any ideas to write. The students do not create good essay without the ideas that appear through critical thinking. Critical thinking is very important in writing an essay. Therefore, the students have to apply a critical thinking in writing.

Critical thinking that is important to develop information through examining, analyzing and evaluating (Paul and Elder, 2014) . The students practice writing and apply their critical thinking to write well. In writing the students employing mind to think of, to analyze, to evaluate, to extend arguments, to criticize something like information in order that find good conclusion or judgment. By applying critical thinking in writing process the students can writing well. The writing well has unity, coherence, and organized ideas.

Critical thinking is one of the key to writing well. For apply critical thinking in writing the students have to analyze, evaluate, and criticize information and issue in order to find good conclusion and judgment with the result the students can write well. Write well has unity, coherence, and organized ideas. Therefore, who will write essay have to apply their critical thinking. The students who have did not apply their critical thinking in writing, they will have been lazy to create good essay because they have did not had ideas anymore. Not only that, they will have not motivated to create an interesting essay because less of ideas. Then, writing will have been burden for students because they have did not known what will have they write. Because they have did not applied critical thinking, therefore 
they have did not had ideas anymore. Next, writing essay will have been boring, because they have not been interesting to write, it has happened because less of ideas that will write.

The students who have talent in writing without apply their critical thinking they do not develop the potential that they have. Therefore, talent and potential will hide and will not develop. Not only that, the students' writing achievement will be low. For example, the students can't write an essay also do not create good and interesting essay. it supports that through writing the students can apply their critical thinking like analyze, synthesize and evaluate information (Saputra, 2018).

An achievement is which someone has succeeded in doing something especially after a lot of effort. Also achievement is the result of the success in doing something that can be seen from their score. The students get score after they have done accomplish a task or assignment. Thus, writing achievement signed a score which students get from their process writing until create a product.
Hatti and Eric (2013:338) state that writing achievement is marked by the ability to product text that extends across a number paragraph that coherence sentence and paragraph are tied into meaningful whole, and that accommodates the need of potential reader. It can be interpreted that writing achievement shows the position how able to make a sentence be a good paragraph.

\section{RESEARCH METHOD}

The design of this research was quantitative research. The researcher used correlation research as a research method. The researcher decided to use it because the researcher wanted to analyze the correlation between critical thinking and writing achievement at the third semester students of English Education Department in STKIP PGRI Sumbar registered 2018/2019 academic year. According to Creswell (2012:338), correlation research is a statistical test to determine the pattern for two (or more) sets of data to vary consistently. It showed that 
correlation research is processing of data that consist of two or more data, where the data influence each other.

This research conducted at STKIP PGRI SUMBAR. Specially, the population had been taken from students at the third semester of English department registered 2018/2019 academic year. According to Creswell (2012:142) that population is a group of individual who have the same characteristic.

Sample is number of students from target population. According to Creswell (2012:142), sample is a sub group of the target population that the researcher plans to study for generalizing about the target population. The researcher use determining sample size and gets 30 participants as sample for this research. ( Late of Florida International University, Soutbern Oregon University, Boston College, \& Boston, 2012) "Educational Research Tenth Edition book by Gay. L. R, Geoffrey E. Mills and Peter Air Asian, 2012, 138, in determining sample size minimum acceptable sample sizes depend on the type of research involved. Some researchers cited a sample size of 30 as a guideline for correlational, causal-comparative, and true experimental research. For correlational studies, at least 30 participants are needed to establish the existence or nonexistence relation".). The researcher used two instruments to collect the data. The first instrument was test and the second instrument was documentation.

The first step in technique of data collection, the researcher collected the students writing achievement data through documentation. It gets from English lecturer in English Essay Writing class. Total the score was decide that analyzed by the researcher. The second was the researcher identified the variables to be correlated. The researcher identified and appropriated population of participant from which select a sample. Third, The researcher distributed the Cornell Critical Thinking test for 30 students as the Sample. The test did by online test because we are still in Covid-19 pandemic. 
There are three steps in analyzing the data such as the preparation, tabulation, and the implementation of data based on the approach of research. On the preparation the researcher collected and arrange the data clearly and carefully before analysis the instruments. On the steps, researcher was checked the name, identifies the respondent and complete the data. It was complete the students' critical thinking skill test and document. Then, the tabulation In this study the researcher did some steps to tabulation the score of students critical thinking skill also the document (students English Essay Writing score). In this test, the rating questions with a yes/no/maybe scale and the test have score same for each question that was 1 score for correct answer and 0 score for wrong answer. First, the researcher classifications the students critical thinking score in table form. Then, the researcher will be tabulation by formula suggested by Arikunto (2006:236). Implementation, After the score of students critical thinking test and document was got by researcher, the researcher analyzing data to get correlation between critical thinking and writing achievement, the researcher will use Pearson Product Moment Formula from (Chee \& Queen, 2018).

\section{FINDINGS AND DISCUSSION}

In this step, the researcher arranges the data clearly to easier in tabulation the data. The data was inputted in table of scoring and the researcher used Mc. Excel for scoring the students' critical thinking score. The results of students' critical thinking and English Essay Writing were inputted into tabulation. In the tabulation, X gets from students' critical thinking score. In this test, the rating questions with a yes/no/maybe scale and the test have score same for each question that was 1 score for correct answer and 0 score for wrong answer. After 30 students finished fill the questionnaire, the researcher totaled the score with Ms. Excel of the test from the students. Then, score from the test would be $\mathrm{X}$ in tabulation and $Y$ get from student's writing achievement. The researcher got the students' writing achievement 
(especially students English Essay Writing) from the lecturer who thought the English essay writing. The last step is $\mathrm{XY}$, it got from score of students' critical thinking and writing achievement (especially students English Essay Writing) and the researcher totaled Score for gets the $\mathrm{XY}$ in tabulation.

After the two instruments being scored and the researcher had made the tabulation of students' critical thinking and writing achievement of the score of English Essay Writing students. The researcher analyzed them by using Pearson Product Moment $\left(r_{x y}\right)$ to know the coefficient correlation between them both.

The researcher found the interval correlation is middle correlation because the coefficient correlation resided in $0,40-0,70$ therefore, 0,635 in middle correlation categorized. Next, the researcher found $\mathrm{t}$ count $=4,360$ and $\mathrm{t}$ table $=$ 0,3610 in the degree of freedom $(d f)$ $n-2$ where the level of significance (a) 0,05 .
$\mathrm{DF}=\mathrm{N}-\mathrm{nr}$

$=30-2$

$=28$

Based on the data that has been analyzed by the researcher, the researcher will be explained the data above, $\mathrm{T}_{\text {count }}=4,360$ was higher than $\mathrm{T}$ table $=0,3610$. It means that students' critical thinking had significant and middle correlation.

Based on the data analysis above, The researcher found that $\mathrm{T}_{\text {count }}=4,360$ was higher than $\mathrm{T}_{\text {table }}=$ 0,3610 in the degree of freedom $(d f)$ $n-2$ where the level of significance (a) 0,05 . Also the researcher fond that the score of Pearson coefficient (r) reside in 0,635 it means That it goes to +1.00 rather than -1.00 According to Arikunto (2010:322) states that "Arah korelasi, dinyatakan dalam tanda + (plus) dan - (minus). Tanda + menunjukkan adanya korelasi sejajar searah, dan tanda - menunjukkan korelasi sejajar berlawanan arah"'It means that symbol + (plus) is positive correlation and symbol - (minus) is negative correlation. Therefore, it could be concluded that there was a positive correlation between critical 
thinking and writing achievement at the third semester students of English Education Department in STKIP PGRI Sumbar registered 2018/2019 academic year. The researcher interpreted the research result after analyzing the data because the researcher had gotten and know about research findings. The result of research finding showed that correlation between critical thinking and writing achievement could be classified as have middle correlation and there was significance and positive correlation between critical thinking and writing achievement. Furthermore, this research was supported by the other researcher of (Saputra, 2018) found that positive correlation between critical thinking and writing achievement. On the other researcher interpreted that critical thinking had influenced toward writing achievement (63\%), this mean that critical thinking had relation with writing achievement. The researcher found that correlation was positive correlation. Thus, it could be interpreted that critical thinking have middle correlation to writing achievement. In addition, critical thinking was important to increase the writing achievement. For instance, students who got high score of critical thinking and would got high score of writing achievement. In other words, in this research the researcher found that critical thinking had correlation with writing achievement.

\section{CONCLUSION}

Based on finding as study already discuss in the previous chapter, the researcher conclude that, $\mathrm{T}_{\text {count }}=4,360$ was higher than $\mathrm{T}_{\text {table }}=$ 0,3610 in the degree of freedom $(d f)$ $\mathrm{n}-2$ where the level of significance ( $\alpha$ ) 0,05 . It means that the hypotheses in this research accepted. The research found coefficient correlation of this research was 0,635 in middle correlation categorized In conclusion, there was significance correlation between critical thinking and writing achievement at the third semester students of English Education Department in STKIP PGRI Sumbar registered 2018/2019 academic year. 


\section{REFERENCES}

Arikunto, Suharsimi. (2010). Prosedur Penelitian: Suatu Pendekatan Edisi Revisi $V$. Yogyakarta: Rineka Cipta

Bernstein, A. G., \& Isaac, C. (2018). Critical Thinking Criteria for Evaluating Online Discussion The Importance of Critical Thinking within Online Discussion The Importance of Online Discussion for Critical Thinking Evaluative Criteria of Rubrics as Prompts for Meaningful Discussion Rubrics, 12(2), 1-8. Retrieved from https://doi.org/10.20429/ijsotl.2 018.120211

Changwong, K. (2018). Critical Thinking Skill Development: Analysis of a New Learning Management Model for Thai high Schools, 11, 37-48. https://doi.org/10.14254/20718330.2018/11-2/3

Chee, J. D., \& Queen, T. (2018). Pearson's Product-Moment Correlation: Sample Analysis Pearson's Running head: PEARSON ', (January 2013).

Golpour, F. (2014). Critical Thinking and EFL Learners

Performance on Different Writing Modes, 18(1), 103-119.
Putri, R. O. (2018). Investigating the Link between Critical Thinking Skill and Argumentative Writing Skill: The Case of Islamic Senior High School, 5(2), 144153. Retrieved from athttp://jurnal.radenfatah.ac.id/i ndex.php/edukasi

Saputra, A. J. (2018). The Correlation Between Critical Thinking and Writing Achievement of the Fifth Semester Students of English Education Study Program of UIN Raden Fatah Palembang Achievement of the Fifth Semester Students of English, (June), $\quad 0-13$. https://doi.org/10.5281/zenodo. 1293289

University, L. R. G. L. of F. I., University, G. E. M. S. O., College, P. A. B., \& Boston. (2012). Educational Research (tenth edit). United States of America: Library of Congress Cataloging-in-Publication Data Gay,. 